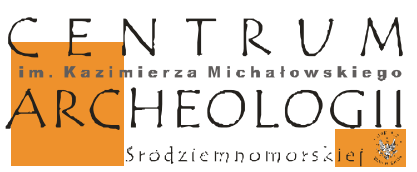

Title: Preliminary report on the 2008 and 2009 excavation seasons at Jiyeh (Porphyreon) With appendices: 1. Sunken vessels in late Roman and Byzantine Houses in area D 2. Preliminary remarks on thresholds from private houses in Jiyeh (Porphyreon)

Author(s): Tomasz Waliszewski, Karol Juchniewicz, Mariusz Gwiazda

Appendices by: Mariusz Gwiazda

Journal: Polish Archaeology in the Mediterranean 21 (Research 2009)

Year: 2012

Pages: 423-445

ISSN 1234-5415 (Print), ISSN 2083-537X (Online)

ISBN 978-83-235-1144-1

Publishers: Polish Centre of Mediterranean Archaeology, University of Warsaw (PCMA UW), Wydawnictwa Uniwersytetu Warszawskiego (WUW)

$\underline{\text { www.pcma.uw.edu.pl }- \text { www.wuw.pl }}$

\title{
PRELIMINARY REPORT ON THE 2008 AND 2009 EXCAVATION SEASONS AT JIYEH (PORPHYREON) \\ Tomasz Waliszewski, ${ }^{1}$ Karol Juchniewicz, ${ }^{2}$ Mariusz Gwiazda ${ }^{3}$ with appendices by Mariusz Gwiazda ${ }^{3}$ \\ 1, 2 Institute of Archaeology, University of Warsaw, \\ ${ }^{3}$ Antiquity of Southeastern Europe Research Centre, University of Warsaw; \\ Institute of Archaeology, Cardinal Stefan Wyszyński University in Warsaw
}

\begin{abstract}
Report from archaeological excavations in 2008 and 2009 carried out at the coastal site of Jiyeh in Lebanon, following up on earlier investigations, by Polish archaeologists. Remains of late Roman-Byzantine dwellings in the central part of the site, excavated originally by a Lebanese mission in 1975, were re-explored including documentation of finds in local museum collections, said to have come from these excavations. Testing in this part of the habitation quarter produced a provisional stratification, from the Iron Age (8th-7th century BC) directly on bedrock, through the Persian-Hellenistic period (5th-2nd centuries $\mathrm{BC})$ to the late Roman-Byzantine age when the quarter has reoccupied. A curious feature consisting of pots sunk in the floor in several of the late Roman and Byzantine-age houses is discussed in the first of two appendices. The other appendix treats on stone thresholds from these houses, five types of which have been distinguished, reflecting different technical solutions used to close doors.
\end{abstract}

Keywords: Jiyeh, Lebanon, housing quarter, late Roman-early Byzantine, Iron Age, thresholds, "milk-bowl" 


\title{
PRELIMINARY REPORT ON THE 2008 AND 2009 EXCAVATION SEASONS AT JIYEH (PORPHYREON)
}

\author{
Tomasz Waliszewski, ${ }^{1}$ Karol Juchniewicz, ${ }^{2}$ Mariusz Gwiazda ${ }^{3}$ \\ with appendices by Mariusz Gwiazda ${ }^{3}$ \\ ${ }^{1,2}$ Institute of Archaeology, University of Warsaw, \\ ${ }^{3}$ Antiquity of Southeastern Europe Research Centre, University of Warsaw; \\ Institute of Archaeology, Cardinal Stefan Wyszyński University in Warsaw
}

\begin{abstract}
Report from archaeological excavations in 2008 and 2009 carried out at the coastal site of Jiyeh in Lebanon, following up on earlier investigations, by Polish archaeologists. Remains of late Roman-Byzantine dwellings in the central part of the site, excavated originally by a Lebanese mission in 1975, were re-explored including documentation of finds in local museum collections, said to have come from these excavations. Testing in this part of the habitation quarter produced a provisional stratification, from the Iron Age (8th-7th century BC) directly on bedrock, through the Persian-Hellenistic period ( 5 th-2nd centuries BC) to the late Roman-Byzantine age when the quarter has reoccupied. A curious feature consisting of pots sunk in the floor in several of the late Roman and Byzantine-age houses is discussed in the first of two appendices. The other appendix treats on stone thresholds from these houses, five types of which have been distinguished, reflecting different technical solutions used to close doors.
\end{abstract}

Keywords: Jiyeh, Lebanon, housing quarter, late Roman-early Byzantine, Iron Age, thresholds, "milk-bowl"

Excavations in Jiyeh in 2008 and 2009 followed two years of forced inactivity in the field, fieldwork in 2006 having been cancelled at the last minute due to political circumstances and 2007 being organized as a study season alone. The PCMA team, which has been working at Chhîm in Lebanon since 1996, had undertaken limited investigations at Jiyeh in 1997 and then again in 2003 when a geophysical survey was carried out in the late Roman necropolis and the Byzantine basilica area. This was followed by salvage excavations on the late Hellenistic pottery production center and late Roman necropolis, conducted in 2004 and 2005. In 2008 the team was able finally to launch full-fledged excavations at Jiyeh, recording in the first season the remains of ancient dwellings in the central part of the site (Area D) and in 2009 studying the stratigraphy of this part of the ancient settlement.

The late antique habitation area situated east of a Christian basilica constitutes only a small section of a vaster complex, different parts of which were mentioned several times by early researchers of the 19th and 20th century (Renan 1864: 
509-514; Contenau 1920: 295-305). The site of Jiyeh (most probably ancient Porphyreon) had been excavated by the Directorate General of Antiquities once, between May and September 1975 (Saidah 1977), when this quarter was discovered.
It suffered extensively from illicit digging after civil war broke out. The large basilica was discovered in effect of clandestine digging in 1988 and the mosaic pavements from the church were lifted and taken to the museum in Beiteddine Palace

Team

Season 2008

Dates of work: 26 July-11 September 2008

Director: Dr. Tomasz Waliszewski, archaeologist (Institute of Archaeology, University of Warsaw) DGA representative: Myriam Ziadé (General Directorate of Antiquities, Ministry of Culture)

Archaeologists: Karol Juchniewicz (Institute of Archaeology, University of Warsaw), Artur Kaczor (independent), Dr. Magdalena Łaptaś (Cardinal Stefan Wyszyński University in Warsaw), Dr. Tomasz Nowakiewicz (Institute of Archaeology, University of Warsaw), Agnieszka Szulc-Kajak (independent), Dr. Mahmoud El-Tayeb (Institute of Archaeology, University of Warsaw)

Archaeologist-ceramologist: Dr. Krzysztof Domżalski (Institute of Archaeology and Ethnology, Polish Academy of Sciences), Urszula Wicenciak (PhD candidate, Pułtusk Academy of Humanities) Architect: Jolanta Juchniewicz (Warsaw University of Technology)

Photogrammetrists: Joanna Czajkowska, Karol Czajkowski (independent)

Documentalists: Julia Górecka, student (Institute of Archaeology, University of Warsaw), Magdalena Makowska (independent)

Student-trainees: Iwona Brodzka, Aleksandra Chołuj, Mariusz Gwiazda, Maciej Harla, Iwona Janeczko, Sylwia Krawczyk, Karol Ochnio, Jarosław Paszkiewicz, Joanna Pazio, Elżbieta Strachocińska, Krystian Trela, Kamil Wojtulewicz, Bartosz Wójcik, Anna Zawadzińska (all from the Institute of Archaeology, University of Warsaw) and Maria Kozińska (Kraków University of Technology)

Season 2009

Dates of work: 27 June-8 August 2009

Director: Dr. Tomasz Waliszewski, archaeologist (Institute of Archaeology, University of Warsaw) Archaeologists: Dr. Mahmud El-Tayeb (Institute of Archaeology, University of Warsaw), Mariusz Gwiazda (PhD candidate, Antiquity of Southeastern Europe Research Centre, University of Warsaw), Karol Juchniewicz (PhD candidate, Institute of Archaeology, University of Warsaw), Zofia Kowarska (Institute of Archaeology, University of Warsaw), Szymon Lenarczyk (Institute of Archaeology, University of Warsaw), Agnieszka Szulc (independent)

Archaeologist, ceramologist: Dr. Krzysztof Domżalski (Institute of Archaeology and Ethnology, Polish Academy of Sciences), Urszula Wicenciak ( $\mathrm{PhD}$ candidate, Antiquity of Southeastern Europe Research Centre, University of Warsaw)

Architect: Jolanta Juchniewicz (Warsaw University of Technology)

Photogrammetrist: Karol Czajkowski (independent)

Photographer: Miron Bogacki (Institute of Archaeology, University of Warsaw)

Documentalist: Angelika Dłuska, Magdalena Makowska (both independent)

Archaeology student-trainees: Iwona Brodzka, Iwona Janeczko, Karol Ochnio, Jarosław Paszkiewicz, Karolina Pawlik, Joanna Pazio, Bartosz Wójcik, Anna Zawadzińska (Institute of Archaeology, University of Warsaw) 
(Jounblat et alii 1989). Archaeological investigations were taken up again in 1997 by the Polish-Lebanese Mission from the PCMA, working at nearby Chhîm (for more detailed reports, see Wicenciak et alii 2003; Domżalski et alii 2005; Waliszewski 2005; Waliszewski et alii 2006; 2007).
The choice of this particular area for comprehensive investigations was determined by external factors, among others, the inability to provide proper protection for uncovered archaeological remains (including a fence).

\section{ROMAN AND BYZANTINE RESIDENTIAL QUARTER IN AREA D}

The area that stretches to the east of the Byzantine basilica comprises substantial remains of a habitation quarter, uncovered and excavated already in
1975 by Roger Saidah. The area cleared in 2008 (approximately $40 \mathrm{~m}$ by $35 \mathrm{~m}$ ) encompassed 77 rooms or other units forming a residential complex criss-crossed

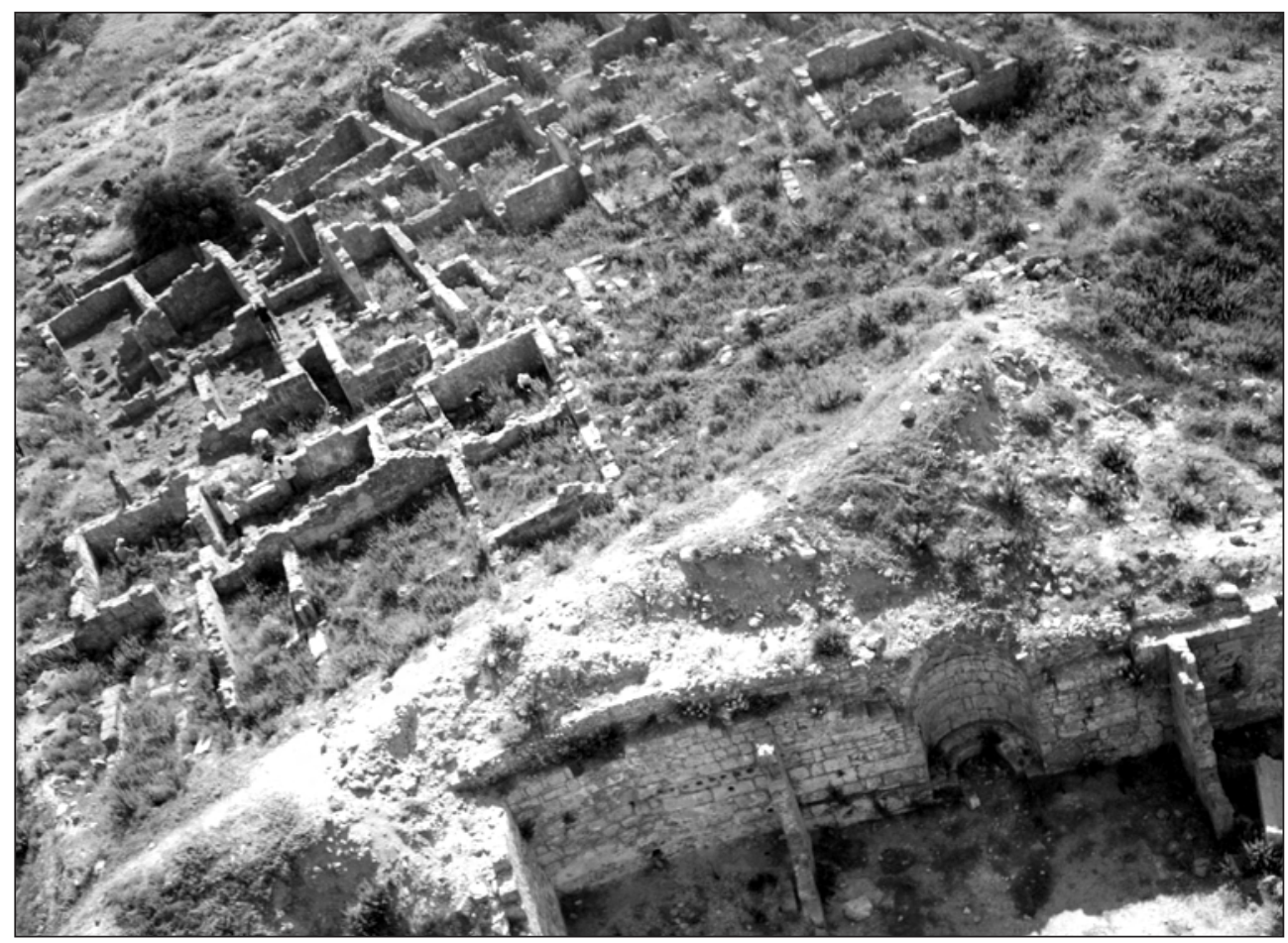

Fig. 1. Residential district and east wall of Byzantine basilica in Jiyeh (Porphyreon): kite-aerial view at the beginning of excavations in 2008 (Photo K. Trela) 
Tomasz Waliszewski, Karol Juchniewicz, Mariusz Gwiazda

LEBANON

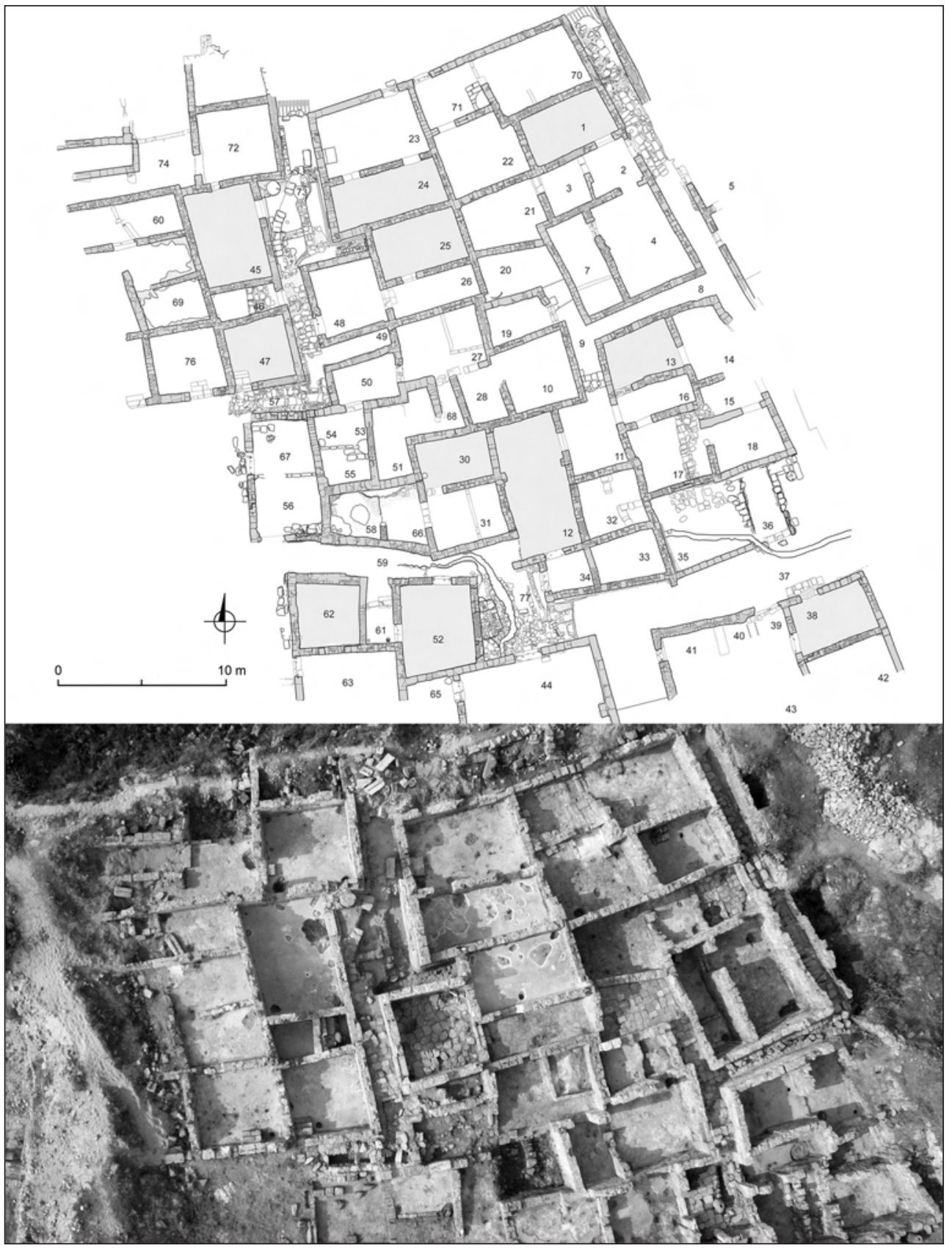

Fig. 2. Plan of area D of the residential quarter in Jiyeh (Porphyreon) and kite-aerial view at the close of excavations in 2008 (Plan J. Juchniewicz; photo K. Trela) 


\section{LEBANON}

by narrow winding lanes [Figs 1, 2; for digital models and orthophotomaps of the excavation area, see Bogacki 2012, in this volume].

The street grid followed no regular plan and was erratic in surface level. The lanes were rather narrow (1-2 $\mathrm{m})$ and paved in the parts overlying the sewage canals [Fig. 3]. Several streets were identified: 9 and 50 going $\mathrm{N}-\mathrm{S}$ and $8,57,59,37$ going E-W. The longest street is more than $20 \mathrm{~m}$ long in the preserved part. Different structures featured in these alleys included a more or less rectangular stone platform at the bend in street 59 and a bench of sorts between the entrances to units 12 and 34 .

The walls of buildings constructed of local sandstone (referred to locally as ramleh) stood more than $2.50 \mathrm{~m}$ high in places (rooms 4, 17, 18). House groundplans, while not standard, shared features, such as a main room with mosaic floor, and smaller mortar-floored rooms and presumably also open stone-paved courtyards organized around it. Mosaics were simple, made of big white cubes, approximately $1.3 \mathrm{~cm}$ to the side, laid in mortar mixed with gravel on a pebble substrate [Fig. 4] The only mosaic floor with a simple geometric pattern of scales drawn with red and black cubes was found in room 63 . House walls were coated on the inside with gray plaster, seldom adorned with inscriptions painted in red, mostly quotations in Greek from the Psalms. ${ }^{1}$ Exterior walls were plastered and, in street 59, additionally reinforced and protected by gravel covered with plaster, the coating applied more thickly at the bottom of the wall. Remains of staircases (rooms 61, 46) attest to the storeyed character of this architecture at least in places, while rains in the streets and under the paving of the house courtyards points to simple, but effective ancient sewage in the village.

At least eighteen complexes of rooms were identified in the excavation area (including units cleared in 2009: 1) rooms $1-2-3-4-7-21$; 2) rooms $23-24$; 3) rooms 48-25-26; 4) rooms 45-?; 5) rooms 47-?; 6) rooms 60-69-?; 7) rooms $13-14-15-18$; 8) rooms $16-17-11-12-$ $32-33-34)$; 9) rooms $10-27-28-68-19$; 10) rooms $30-31$; 11) rooms 51-53$54-55-66-58$; 12) rooms 67-56-?; 13) rooms $44-65$; 14) rooms $52-63 ; 15)$ rooms 62-?; 16) rooms 38-?; 17) rooms 42-?; 18) rooms 39-40-41. Several phases of change could be observed in each of the complexes. Evidence of some

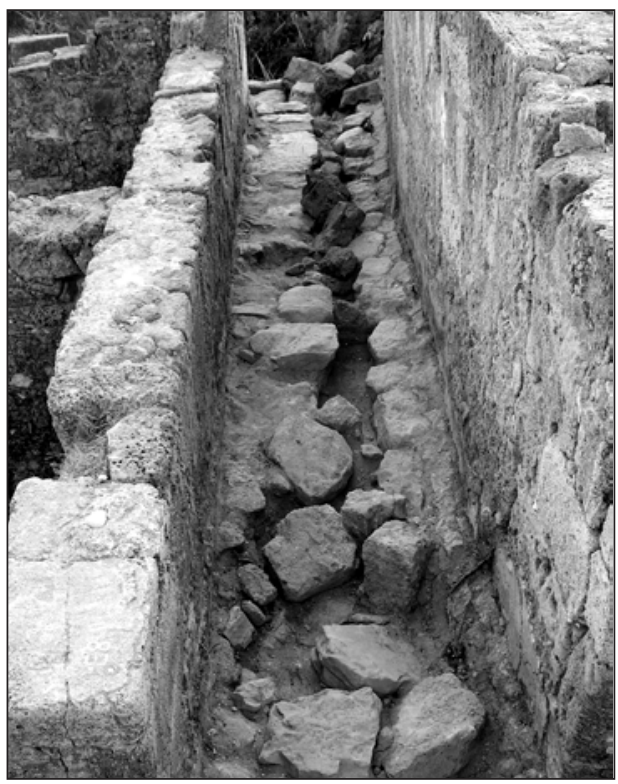

Fig. 3. Street 8 in area $D$ (Photo T. Waliszewski)

Studied by epigraphist F. Alpi from the Institut Français du Proche-Orient in Beirut. 
Tomasz Waliszewski, Karol Juchniewicz, Mariusz Gwiazda
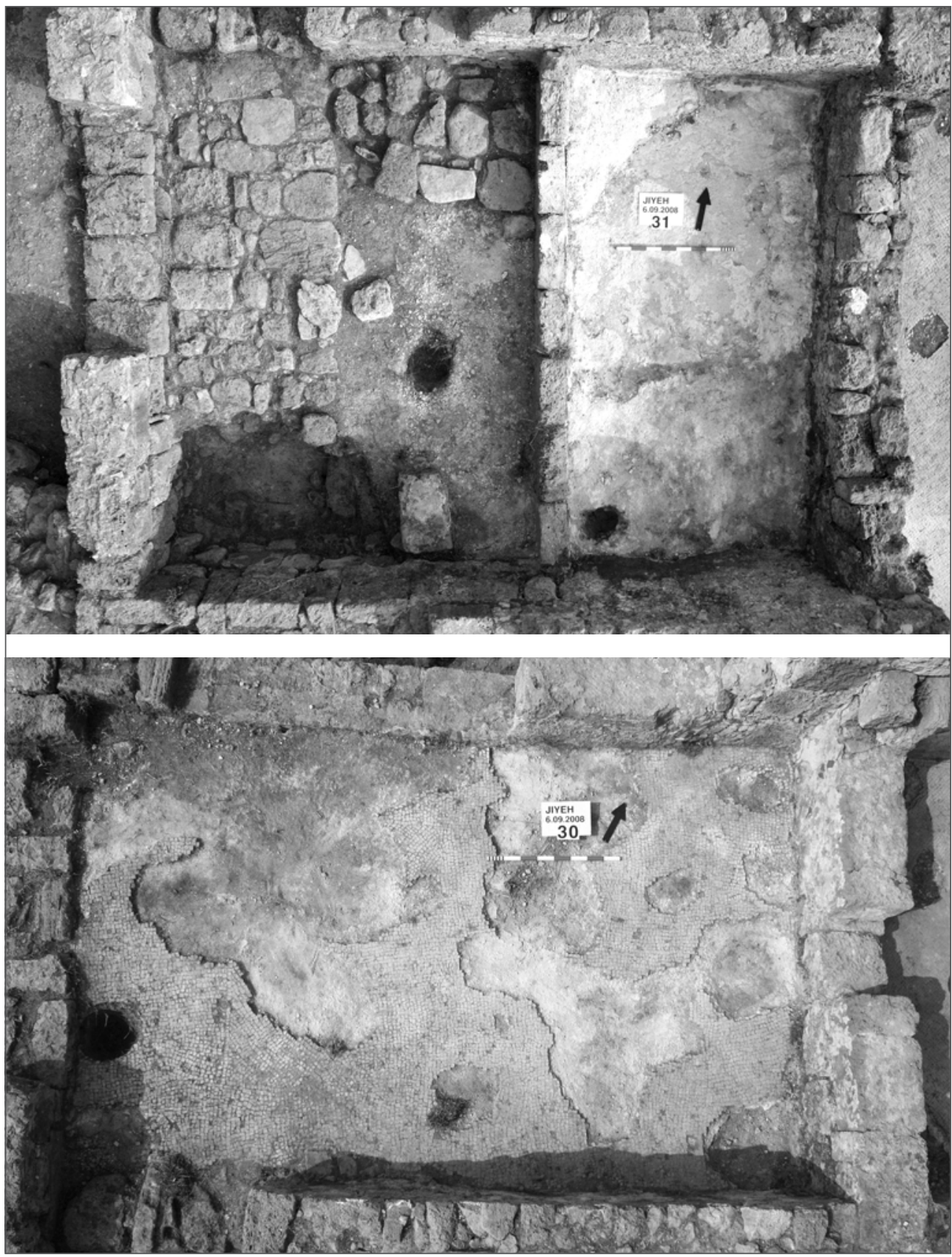

Fig. 4. Top view of the floor surfaces in units 31 (top) and 30, the latter a plain white mosaic floor (Photos K. Trela) 
Preliminary report on the 2008 and 2009 excavation seasons at Jiyeh (Porphyreon)

\section{LEBANON}

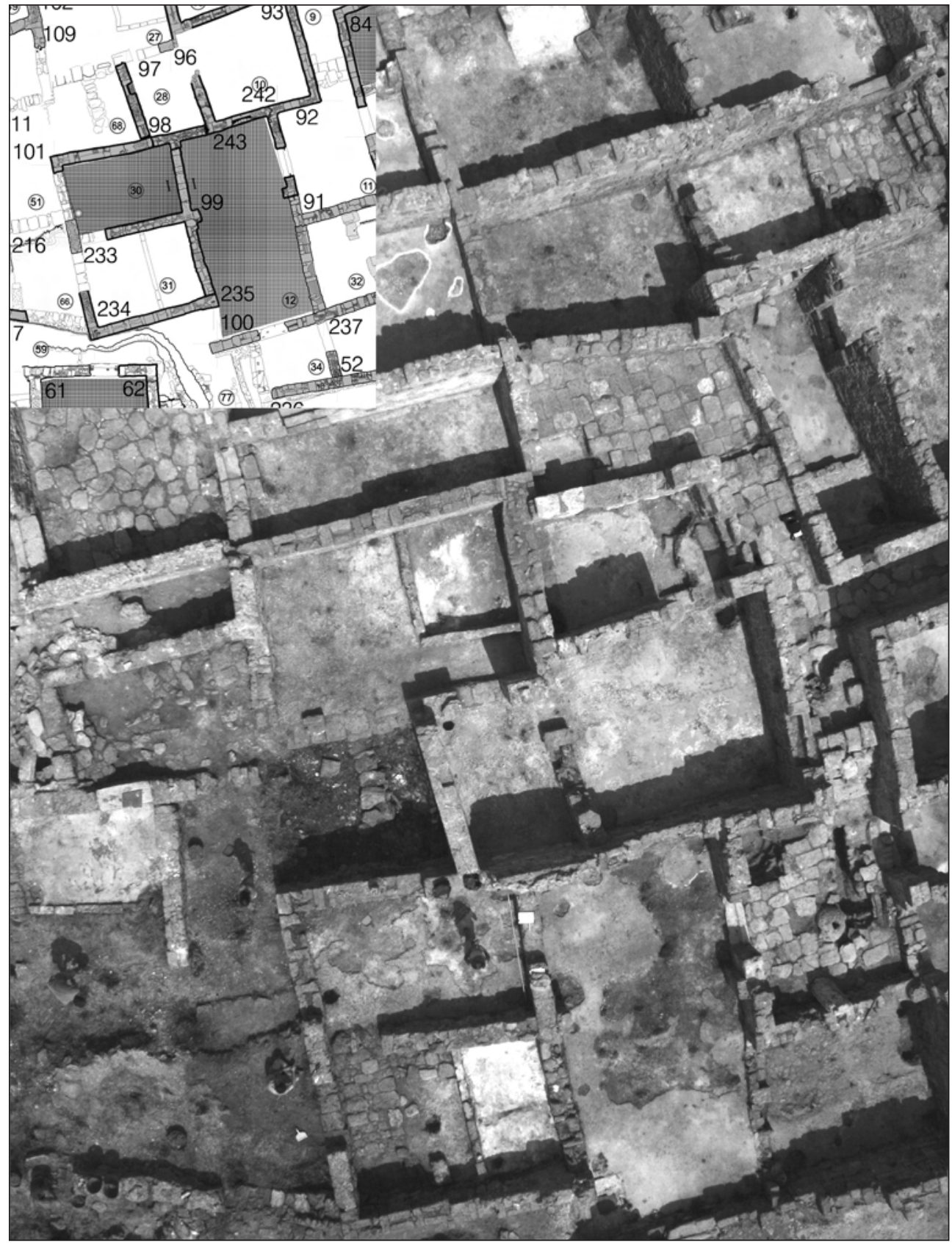

Fig. 5. Rooms around complex 8 in area D, kite-aerial view

(Photo K. Trela) 
of these phases is fragmentary and difficult to discern. No significant chronological appraisal is possible at the moment. Most of the pottery finds came from secondary fill. The forms and fabric of the pottery from this layer are characteristic of vessels from the 6 th to the early 7 th centuries. The course of the sewage system was dictated by the layout of the rooms on the ground, but some structures were also identified below, indicating at least a partial change of alignment and a rebuilding of the existing rooms between the Roman and Byzantine periods. The exact nature of these alterations will be clear once the stratigraphic record of the site is examined in detail.

The architecture was cleared and documented (for remarks on storage vessels found in position inside the units and for a preliminary appraisal of stone thresholds see the appendices to this report).

One of the most imposing houses is Complex 8 [Fig. 5] and it can be described as a model example of the architecture uncovered in 1975 by the Lebanese DGA. It has a central room (12) with mosaic paving featuring a three-tesserawide border around its perimeter laid out in a different pattern from the rest of the floor. Running along each of the longer sides of this room was a line of pillars supporting the ceiling. The shorter north wall was provided with a centrally located, rectangular niche. The central room was flanked by rooms 11,32 and 33 from the east, and 34 from south. Rooms 32 and 33 had mortar floors, while 11 and 34 were paved with stone slabs. At this stage (the phase associated with the mosaic flooring) access to the building was probably gained via the stairway entrance leading to room 12 from street 59. This entrance was located some $60 \mathrm{~cm}$ higher than the mosaic floor level, as was the entrance leading from room 12 to room 34 . Both entrances appear to be associated with the mosaic floor of room 12; however, there are no traces of any stairs leading down to the mosaic level and thus facilitating passage between the rooms under discussion. The complex could also be entered through the courtyard (room 11). This entrance was remodeled and blocked during the next occupation phase. Room 11 was paved with stone slabs covering the sewage canal which ran below. Another entrance was located in room 34 , leading directly out to street 59 , the surface of which was some $60 \mathrm{~cm}$ below the stairs leading to room 12 .

Excavations in 2009 cleared an additional two rooms $(79,80)$ to the west of the complex. The first room abutted a narrow passage dividing it from rooms 76 and 57. A stone sewage channel, approximately $0.40 \mathrm{~m}$ wide and $0.45 \mathrm{~m}$ deep, covered with flat slabs, constituted the walking level of the street. Interestingly, it runs off toward the east wall of the Byzantine basilica, suggesting the existence of a bigger collecting channel somewhere between the dwellings and the wall of the church. The room was rectangular (approximately $3.90 \mathrm{~m}$ by $3.05 \mathrm{~m}$ ). The walls, built of local sandstone, are preserved only to the first course of stone blocks above floor level. The mortar floor itself is preserved only in some places and is generally in very bad condition. The other room was considerably bigger and also rectangular $(9.10 \mathrm{~m}$ by $3.05 \mathrm{~m})$. It sided with room 67 and street 56, but the actual relationship with the street is yet unknown. No evidence of a floor was found and the only feature is a rectangular structure constructed of small stone blocks, presumably sunk into the floor in the eastern 


\section{LEBANON}

and central part of the room. The unit may have been in fact a courtyard linked to street 56 and used for some kind of industrial activity taking advantage of the basin.

The simple, double masonry building technique used for the walls, their random structure and the winding, narrow streets demonstrate the general simplicity of the architecture, reminiscent of some of the present-day houses seen in villages and cities in the region. The most striking similarities are provided by a nearby site at Khan Khalde (Saidah 1975), situated some $20 \mathrm{~km}$ north of Jiyeh, and the site of Kfar Samir (probably ancient
Porphyreon South), uncovered during rescue excavations just south of modern Haifa (Finkielsztejn 2005), both within the limits of the late antique province of Phoenicia Maritima.

Further work is required on the borders of this quarter, in houses to the south and on the lanes running along the northern and eastern sides The huge sand dune between the last line of units (including rooms 79 and 80) and the Byzantine basilica [see Fig. 1] should also be removed in order to complete the first stage of the archaeological project.

$[\mathrm{TW}]$

\section{STRATIGRAPHIC TESTING IN AREA D}

In the meantime work concentrated on testing inside the habitation quarter in an effort to establish the stratigraphy of the site. Five pits were excavated in the course of the 2008 and 2009 seasons.

\section{TEST-TRENCH AT THE \\ TURN OF STREET 37}

Test pit D37 was excavated in 2008 to test the stratigraphy of the site. It was located in the southern part of the quarter, at the intersection of lanes, its size, $3.23 \mathrm{~m}$ by $2.63 \mathrm{~m}$, corresponding to the width of the lanes. The walls of rooms 33 and 34 constituted its northern boundary.

The bedrock in this trench featured characteristic round openings very much like geological drillings [Fig. 7]. At least three major phases of occupation, starting with the Iron Age, which is associated with the oldest walls $(22+23)$ at the bottom of the trench, were distinguished during the excavation. The underlying layers (contexts 24 and partly 26) were dated by potsherds, including a so-called milk-bowl, to the late Bronze /early Iron ages (see also Wicenciak 2012, in this volume) [Fig. 6; see also Fig. 1:1 on page 448].

Nextcameabroadlyunderstood PersianHellenistic phase which corresponds to the continued use of the wall (3) running $\mathrm{N}-\mathrm{S}$ and the units on either side of it. A wall (3) belonged to a "pillar-and-fill" construction

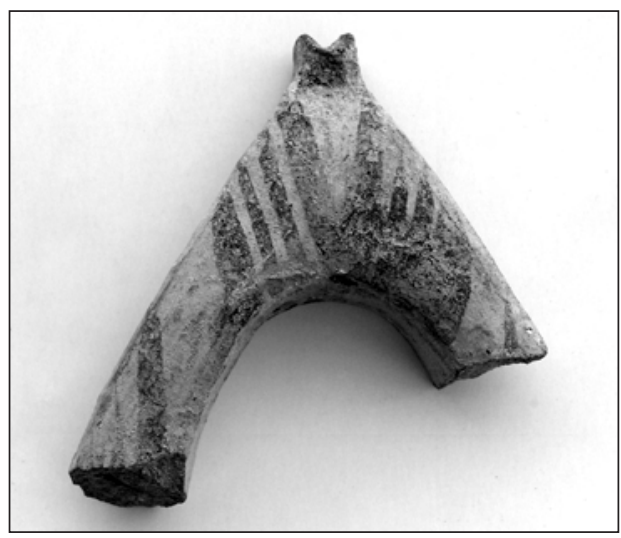

Fig. 6. "Milk-bowl" sherd from test pit D37 (Photo K. Juchniewicz) 


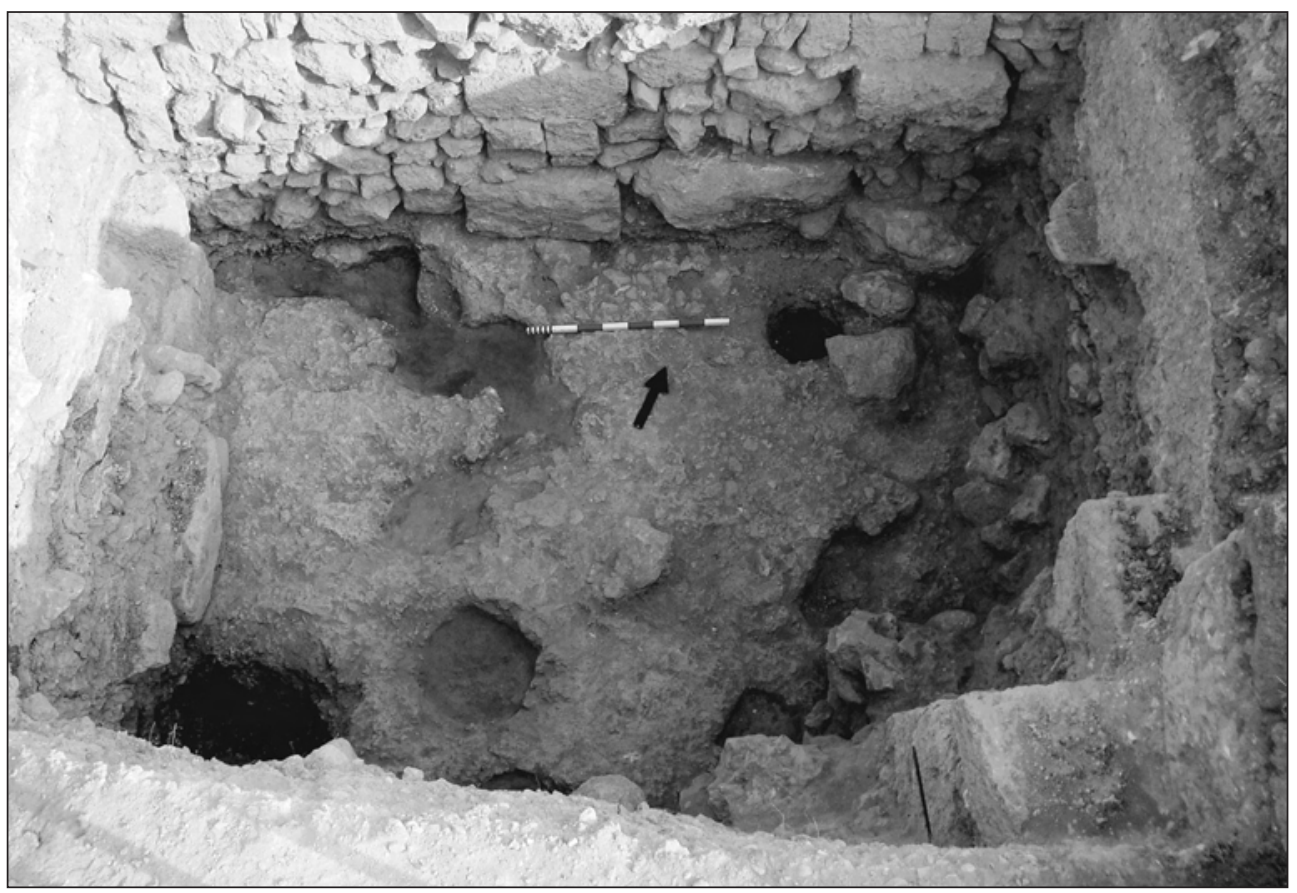

Fig. 7. Bedrock seen in test trench D37 (Photo K. Juchniewicz)

typical of so-called Phoenician building techniques from the Iron Age. The pier of stone blocks is flanked by sections of walls made of pebbles to the north and south [Fig. 9, top] The wall underwent some alterations later on, although the early Roman period is hardly attested, at least in the architecture.

Context 5 distinguished just under the topsoil to the west of the wall was characterized by a mixed pottery assemblage, dated provisionally between the 1st century BC and the 1st century AD. The walls of area 33 erected on top of the Iron Age structures belong to late antiquity and could be indicative of extensive rebuilding of this part of the habitation quarter.

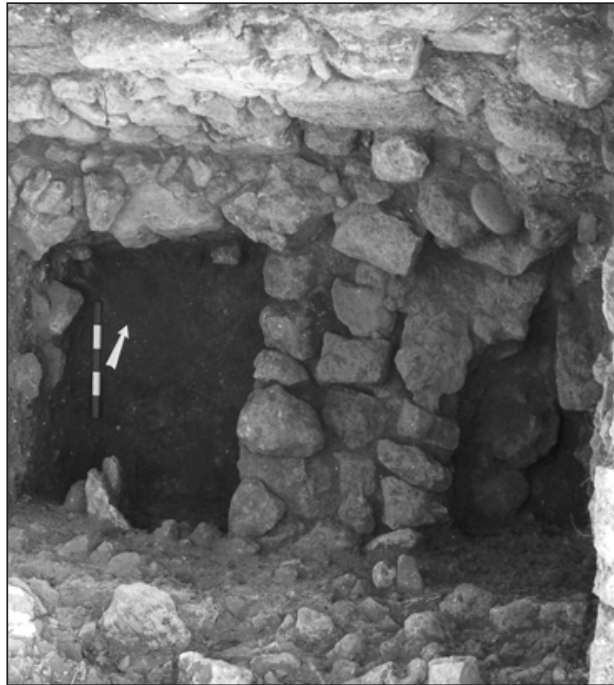

Fig. 8. Stone wall (21) of Iron Age date in trench D44 (Photo K. Juchniewicz) 
Preliminary report on the 2008 and 2009 excavation seasons at Jiyeh (Porphyreon)

\section{LEBANON}

\section{TEST-TRENCH IN ROOM 44 (AREA D)}

The test trench in room 44 in the southern part of the habitation quarter, at the intersection of lanes 37 and 77, was aimed at establishing the extent of the work done by Roger Saidah in 1975. The trench, measuring approximately $5 \mathrm{~m}$ by $2.50 \mathrm{~m}$, was bordered on the north, east and west by standing walls, and on the south by

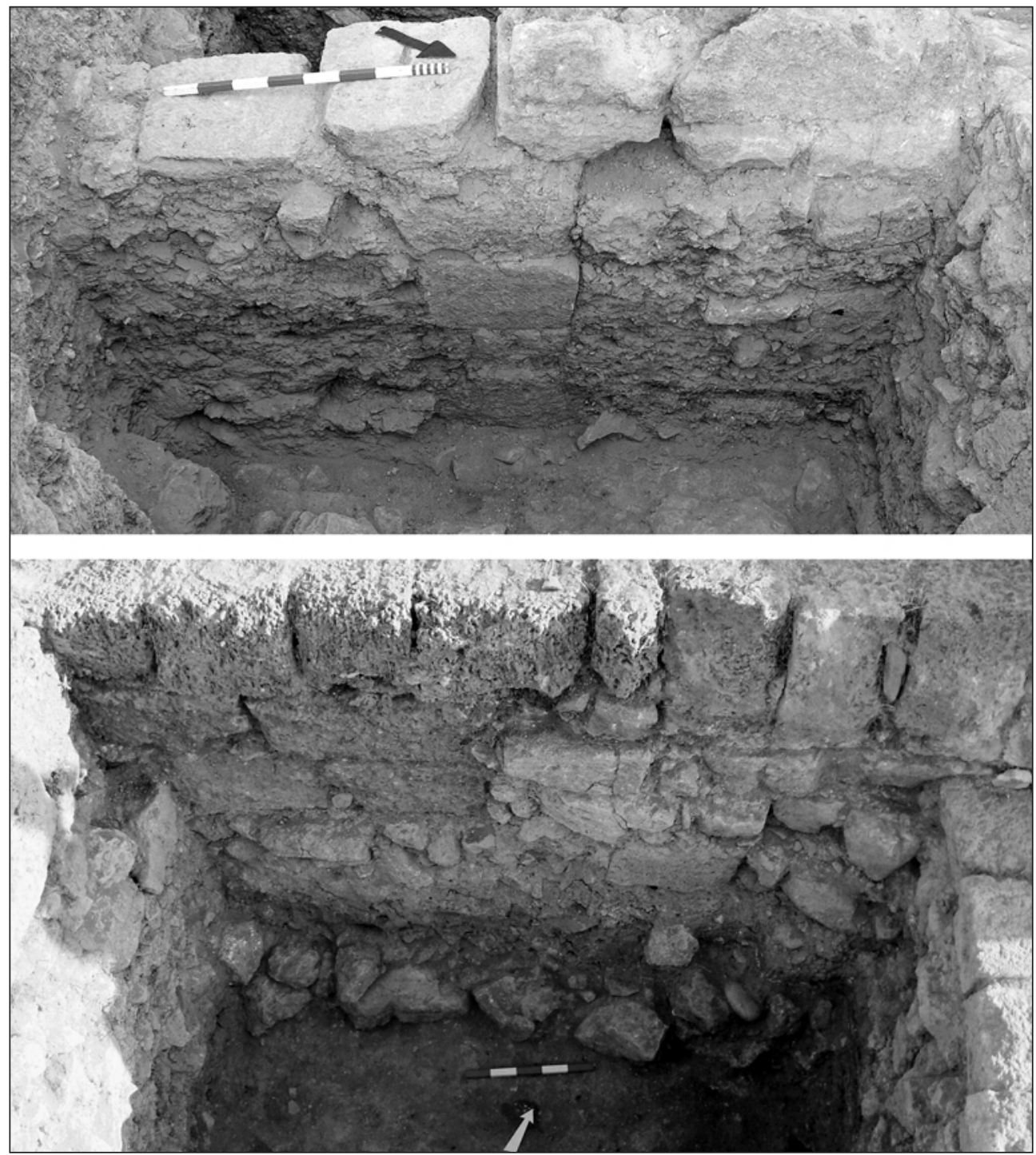

Fig. 9. "Pillar and fill" wall (context 3) from test pit D37 (top) and from trench D44 (Photos K. Juchniewicz) 
the archaeological dumps of the Lebanese expedition.

Phasing of the results achieved in this trench confirmed the general sequence. The site was settled in the Iron Age. A stone structure (21) under layer 17 [Fig. 8] turned out to be a wall built of unbonded stone blocks. It ran perpendicularly to the north wall of room 44 , at a slight angle, disappearing under context 20 , which is the foundation. The context associated with the structure was dated provisionally to the early Iron Age by the ceramic finds.

The next layer which filled the entire trench (context 17), consisted of loose redbrown earth. A possible hearth (18) and a layer of small gravel (19) superimposed on this layer by the eastern trench wall, suggests that it was a habitational level. On the north this layer was bordered by a stone structure which was probably the foundation of the north wall of room 44 . In the upper parts of this wall it was built of local sandstone blocks, but lower down the wall demonstrates a characteristic 'Phoenician' bonding [Fig. 9, bottom]. The layer produced a mixed Persian/Hellenistic and Roman pottery assemblage.

A layer (3) of reused blocks of local sandstone appeared under the topsoil in the western part of the trench, attesting to a modern attempt at protecting the

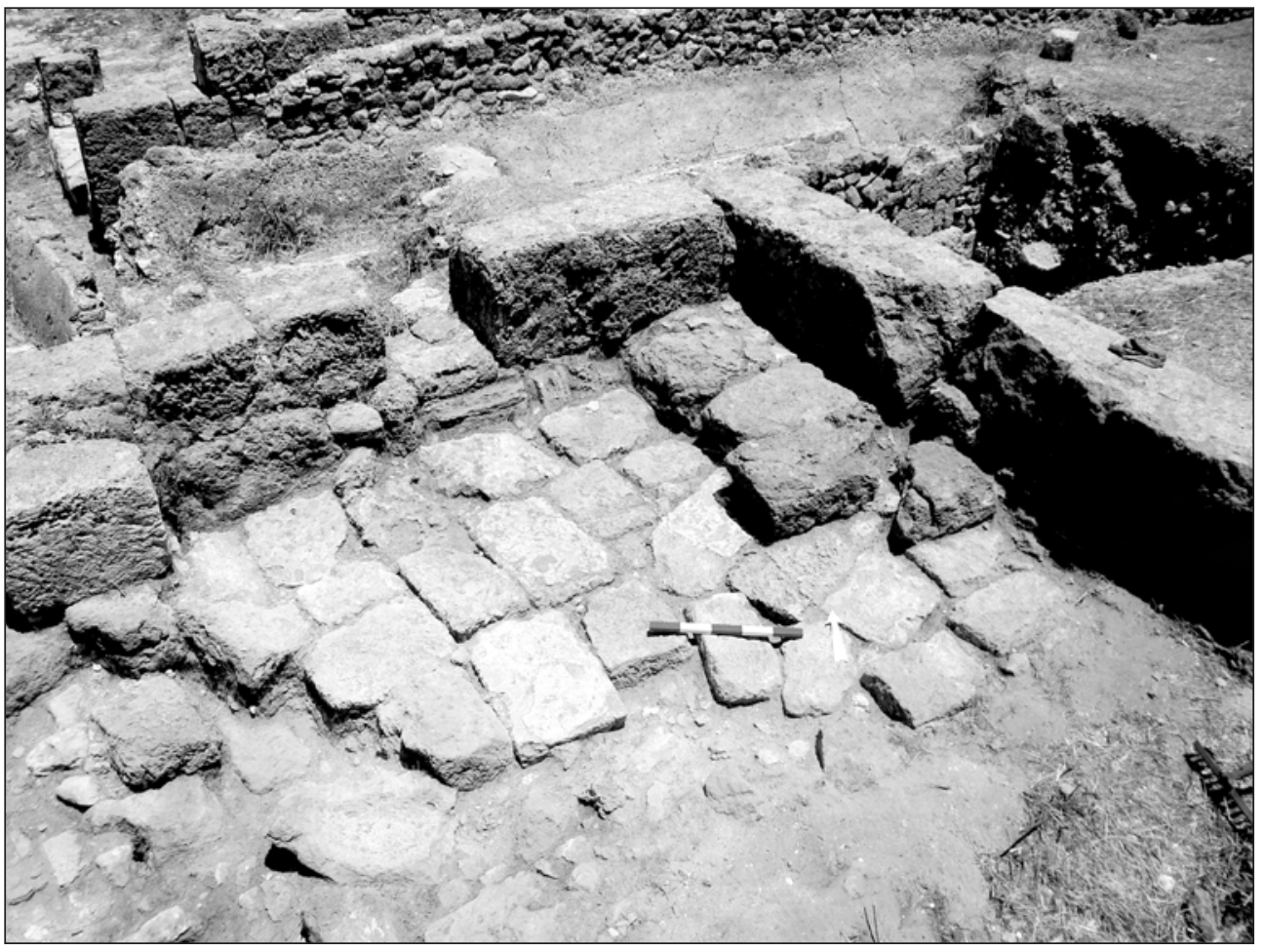

Fig. 10. Layer of reused ramleh blocks in Room D44 at the beginning of the season in 2008 (Photo K. Juchniewicz) 


\section{LEBANON}

archaeological layers uncovered most probably during excavations in 1975 [Fig. 10]. Two of the blocks bore traces of wall painting, including a cross painted red on a lime ground. The channel that reached the room from the north turned out to be a drain discharging rainwater from the roof. It was not continued under room 44.

Excavations were abandoned in the eastern part of the trench because of the limited space and threat of baulk collapse. A boulder found under layer 39 appeared to be part of the bedrock. The considerable depth of the trench, limited space and absence of archaeological material determined the end of work in the trench.

$[\mathrm{KJ}]$

\section{TEST-TRENCH IN ROOM 20 (AREA D)}

The test trench in room D20, excavated in 2009 , aimed at a better understanding of the chronological phasing of settlement in the village. The room is situated at the end of a cul-de-sac in the northeastern part of the habitation quarter. The trench, in the western part of this room, was rectangular, limited on the north, west and south by the room walls.

The following interpretation has been proposed for the recorded stratigraphic sequence based on a preliminary consideration of the ceramic finds. A terminus ante quem for the wall in the lowest part of the trench together with the superposed limestone boulders was provided by the pottery from context $\mathrm{N}$ dated provisionally to the Iron Age II. Later, but still in the Iron Age II, the stone pavement (L) was constructed; this is attested by pottery from both under and above the pavement. The overlying thick rubble layer $(\mathrm{K})$ can be dated to the Persian period. A new pavement (J) was laid in the end of the Persian period or in early Hellenistic times. Walls of the "pillar-andfill” type, also referred to as a Phoenician bond [see Fig. 9], were built (on this kind of structure, see Elayi 1996); later walls, now standing on the ground surface, were aligned with these remains. The pavement was covered with a thick deposit (I) and a thinner one $(\mathrm{H})$. Both deposits contain considerable quantities of early and late Hellenistic ceramics, mixed with Roman amphorae from the 3 rd century AD. The top of fill I reached the preserved crests of the so-called Phoenician wall, which served, presumably in the Roman period, to raise new walls made solely of evenly cut sandstone blocks bonded in regular masonry mortar. Layer I must have served

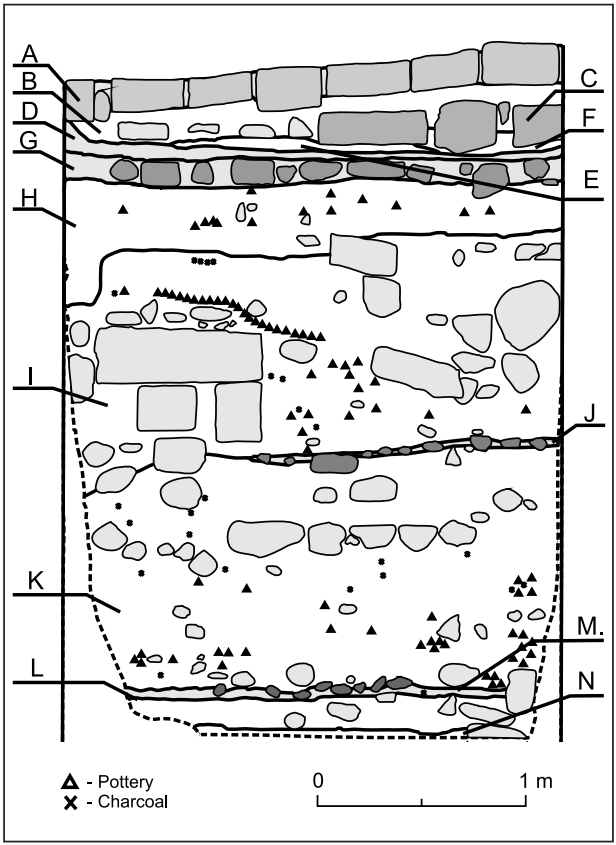

Fig. 11. South wall and trench wall in room D20 (Drawing M. Gwiazda) 
as bedding for stone pavement $G$, which can be dated based on the pottery to the early Roman period. In the next century it was sealed with a mortar floor (D) which was associated with the lower edges of wall plaster on the north, west and south walls of room D20 [Fig. 11].

The appearance of fill I and leveling layer $\mathrm{H}$ containing mixed pottery dated from the Early Hellenistic to the 3rd century AD, as well as a new pavement and walls raised to a new height points to a fundamental reconstruction of this part of the habitation quarter in the Roman period.

Further alterations took place in room D20 in the 4th century AD. Another occupational level in the form of stone pavement $C$ can be observed next to the mortar floor $\mathrm{D}$. This in turn, after suffering partial damages, was sealed with another stone pavement (A), which is given a terminus post quem by pottery found

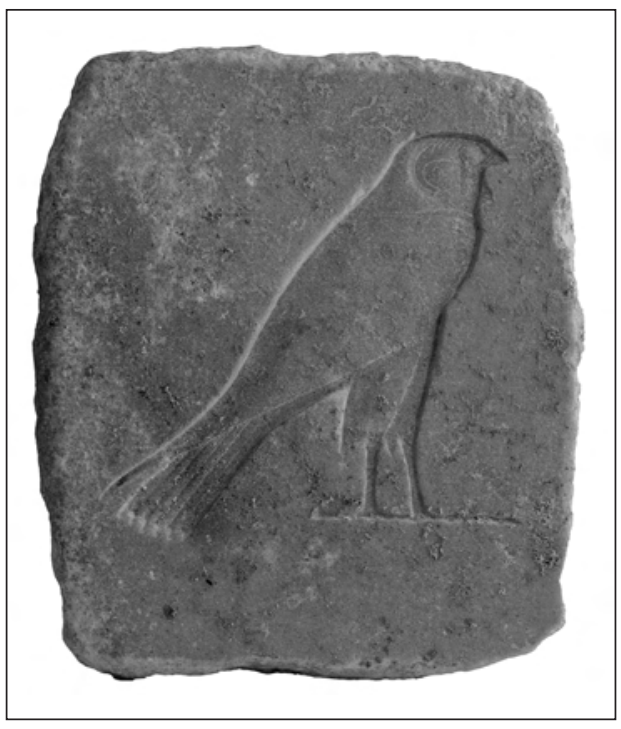

Fig. 12. Relief marble slab with an image of Horus (Photo M. Bogacki) in leveling layer B from the 3rd and 4th centuries $\mathrm{AD}$. The presence of a painted ornament on a plaster ground on the bottom of one of the blocks used in pavement A also demonstrates that the material used in the making of this pavement was salvaged from ruined architecture, presumably in the close vicinity.

A relief marble slab with an image of Horus as a falcon [Fig. 12, see also below, Fig. 2 on page 457] was found in fill I, $1.44 \mathrm{~m}$ below ground surface. The slab measured $40 \times 35 \times 7 \mathrm{~cm}$; the shallow bas relief was carved in a slab where the background was never cut. An irregular outline and chisel marks on the edges and back indicate that the relief was cut from a bigger fragment. Horus was shown in profile, turned to the right, no feathers marked. The carving style and the contextual dating place the relief in the Hellenistic period; parallels can be found among Ptolemaic limestone models now in the Egyptian Museum in Cairo (Grimm 1975: 61, Pl. 101; Edgar 1906: $\mathrm{X}$, Nos 33456-33458; on Egyptian cults in Phoenicia, Aliquot 2004).

[MG]

\section{TEST TRENCH IN ROOM 4}

Rectangular room $4(4.00 \times 5.75 \mathrm{~m})$ was chosen for the fourth test trench, which for reasons of limited time covered an area of only $2.20 \mathrm{~m}$ by $3.20 \mathrm{~m}$ in the northeastern corner. A well preserved mortar floor on a bedding of pebbles appeared directly under Byzantine fill, the latter being $0.25-0.30 \mathrm{~m}$ thick. The pottery material excavated directly under the floor suggests a Roman period date for the feature. A wall going north-south was discovered some $0.15 \mathrm{~m}$ under the floor. It was apparently well constructed, approximately $1.40 \mathrm{~m}$ wide. The western façade survived about 


\section{LEBANON}

one meter higher than the central and eastern parts. The wall was associated with a brown-gray layer of soil containing mixed Early Roman-Hellenistic-Iron Age pottery material. The trench was stopped at a depth of approximately $1.60 \mathrm{~m}$ and will be continued.

[TW]

\section{TEST-TRENCH IN ROOM 72}

Another limited test trench was opened in room $72(4.25 \times 4.00 \mathrm{~m})$ situated in the northwestern part of the dwelling zone. A mortar floor level uncovered already by Roger Saidah's team in 1975 was cleared in 2008 , then a test pit was cut in the floor in the southwestern corner of the room in 2009. A wall going east-west was discovered directly under the floor, some $0.20 \mathrm{~m}$ below this level, which should be dated to the Roman period. The feature, approximately $0.70 \mathrm{~m}$ thick, was constructed of small stones and was associated with a layer of gray-brown soil containing mixed Early Roman-Hellenistic-Iron Age ceramics. The trench was stopped at approximately $1.50 \mathrm{~m}$ and will be continued.

A well preserved terracotta vessel sunk into the Roman-period floor was found in the southwestern corner of the trench, directly beside the steps leading to room 74. The pot is apparently one of a series of several similar installations located in different rooms in Jiyeh (see below, appendix 1).

$[\mathrm{TW}]$

\section{FINDS DOCUMENTATION}

In 2009 the team focused on documenting artifacts from Jiyeh stored at the National Museum in Beirut and the Museum of Beiteddine Palace.

The National Museum holds the only assemblage of finds kept after the DGA excavations at Jiyeh by Roger Saidah in May through September 1975. A provisional list of these objects was made in 2005 and a team of four specialists worked on the documentation of these finds in 2007 and in 2009. About 200 of the listed 600 objects: coins, pottery sherds, oil lamps and a prevalence of diverse metal objects, including iron and bronze nails, weights, vessels, candelabra etc., have been drawn, photographed and described. Plans exist for a separate publication of this material, which constitutes a unique document of the 1975 season of fieldwork at the site.

Another important assemblage of objects said to be associated with the

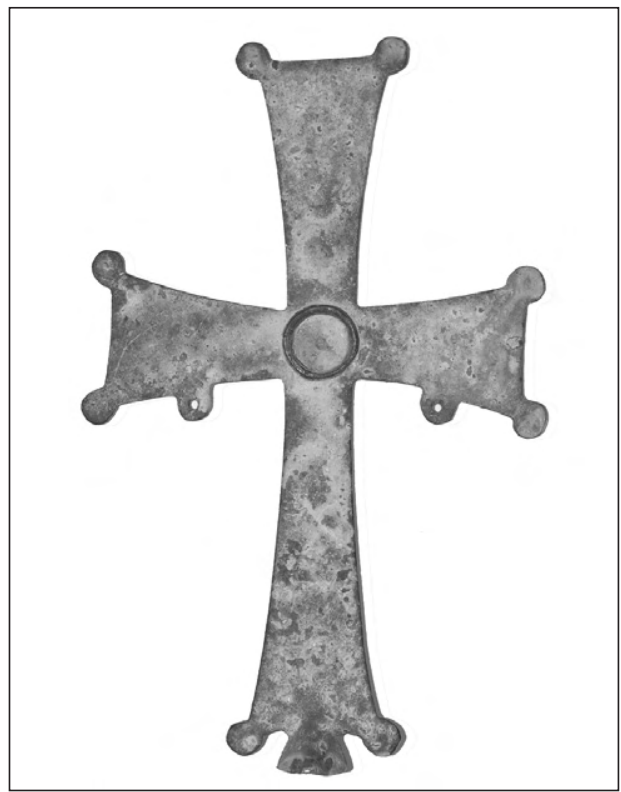

Fig. 13. Byzantine bronze cross from the Museum of Beiteddine Palace, probably from Jiyeh (Photo M. Bogacki) 
site of Jiyeh is held by the Museum of Beiteddine Palace. Circumstances of discovery in this case are mostly obscure. A small team of documentalists spent five days (July 20-24) working in close cooperation with the Direction Géneral des Antiquités (DGA) to record some 65 objects, provisionally dated to the Roman and Byzantine periods. Among the most interesting objects one should mention the bases of two candelabra and a large bronze cross (similar crosses dated usually to the 6th-7th century $\mathrm{AD}$ are known from other regions of Eastern Mediterranean, e.g. Mundell Mango 1986: 90-91 Cat. Inv. No. 8, and 249 Cat. Inv. No. 76) [Fig. 13].

\section{CONCLUSION}

The exploration of the habitation quarter in Jiyeh is of twofold significance: it will allow the Lebanese excavations of 1975 to be published finally and it will permit a deeper understanding of the history of this part of the ancient town through continued research on the stratigraphy of underlying layers.

Once the late Roman and Byzantine dwellings were cleared again, it was possible to trace several separate dwelling units and to characterize on these grounds the domestic urban architecture common to Phoenician coastal towns. Local sandstone was the preferred building material and the houses were grouped together in a kind of insula, communicating via a network of narrow lanes. This architecture was significantly different in character from the limestone building present in the mountain villages of the Limestone Massif in Syria, Chhîm in Lebanon and Galilee in the south. It merits note that Jiyeh has produced the only such architectural complex known to date from the Lebanese coast. Parallels are few, coming mainly from the Palestinian coast and southern Phoenicia; the site of Kfar Samir near modern Haifa remains the nearest example from late antiquity (see Finkielsztejn 2005).
At the same time, testing in a number of places inside the habitation quarter has produced data for analyzing the stratigraphic sequence of Jiyeh (Porphyreon) as such, but also reflecting the history of settlement on the Phoenician coast in the Iron Age, as well as the RomanByzantine period, as well as regarding the continuity or lack of continuity of occupation in the Hellenistic age. The issue had seldom been discussed before in Lebanese archaeology, mainly for lack of stratigraphic studies.

The five test trenches dug in Jiyeh in the course of the reported seasons have led to preliminary observations which will be verified in future research. Trenches in D20, D37 and D44 have produced clear evidence of three architectural phases at least in these parts of the quarter. The oldest phase, connected with relics of stone architecture founded on a sand and earth level directly on bedrock, can be dated to the 8 th-7th century BC. The next phase is separated from the first by an accumulation of $1.00-1.50$ $\mathrm{m}$. The architecture of the second phase is characterized by bondwork referred to frequently in publication as the so-called 'Phoenician' bond. It comprised pillars 
erected of well-dressed blocks at regular intervals, the gaps between them filled with smaller stones. Pottery from contexts adjoining structures of this phase invariably points to a Persian-Hellenistic date (primarily 5th-2nd century $\mathrm{BC}$ ). The youngest phase, considered RomanByzantine on the grounds of the pottery evidence, stands on top of the walls of the preceding phase, but employing an entirely different bond. It comprises courses of medium-sized sandstone blocks, which was the typical building material for dwelling architecture of the period. The stratigraphic sequence recorded in trenched D4 and D72 fully confirmed these observations despite having yet to reach the 8 th- 7 th century BC level.
Current views on site chronology at Jiyeh have had to be modified substantially as a result of this season's work. The origins of the settlement can now be placed provisionally in the Iron Age. Analyses of the material from the trenches, including pottery, glass and coins, are underway and until they have been completed, the conclusions presented here need to be considered as provisional. It remains an open question why the site was abandoned, for the first time in the Iron Age II phase and then following the Persian-Hellenistic occupation. Neither can the passage to the late Roman-Byzantine phase be evaluated in detail as yet. Research planned for the coming season will address these questions in particular.

\section{APPENDIX 1 \\ SUNKEN VESSELS IN LATE ROMAN AND BYZANTINE HOUSES IN AREA D}

\section{Mariusz Gwiazda}

Antiquity of Southeastern Europe Research Centre, University of Warsaw, Institute of Archaeology, Cardinal Stefan Wyszyński University in Warsaw

In fifteen rooms of the late Roman and Byzantine dwelling quarter (nos 1, 4, $10,13,14,21,25,28,30,32,38,47$, $52,72,76)$ there were ceramic pots with a diameter of the mouth from a dozen to a few dozen centimeters. They were sunk in the ground, their rims slightly below floor level [Fig. 14]. In ten cases the vessels were situated close to the entrances to the rooms, in two they were clearly removed from near the doors (in the remaining three instances the relation could not be established due to the poor condition of the walls).

The vessels have been interpreted in a number of hypothetical ways. They could have been for one, traps for scorpions and vipers. They could have held water as a form of air humidifier. They could have served as garbage cans, as spittoons, basins for washing feet, pots to hold potted plants, such as wormwood to frighten off reptiles 
(Henein, Wuttman 2000: 235, 236). None because they had been emptied off their of these possibilities can be excluded in contents during earlier excavations by the case of the vessels from Jiyeh simply Lebanese archaeologists.

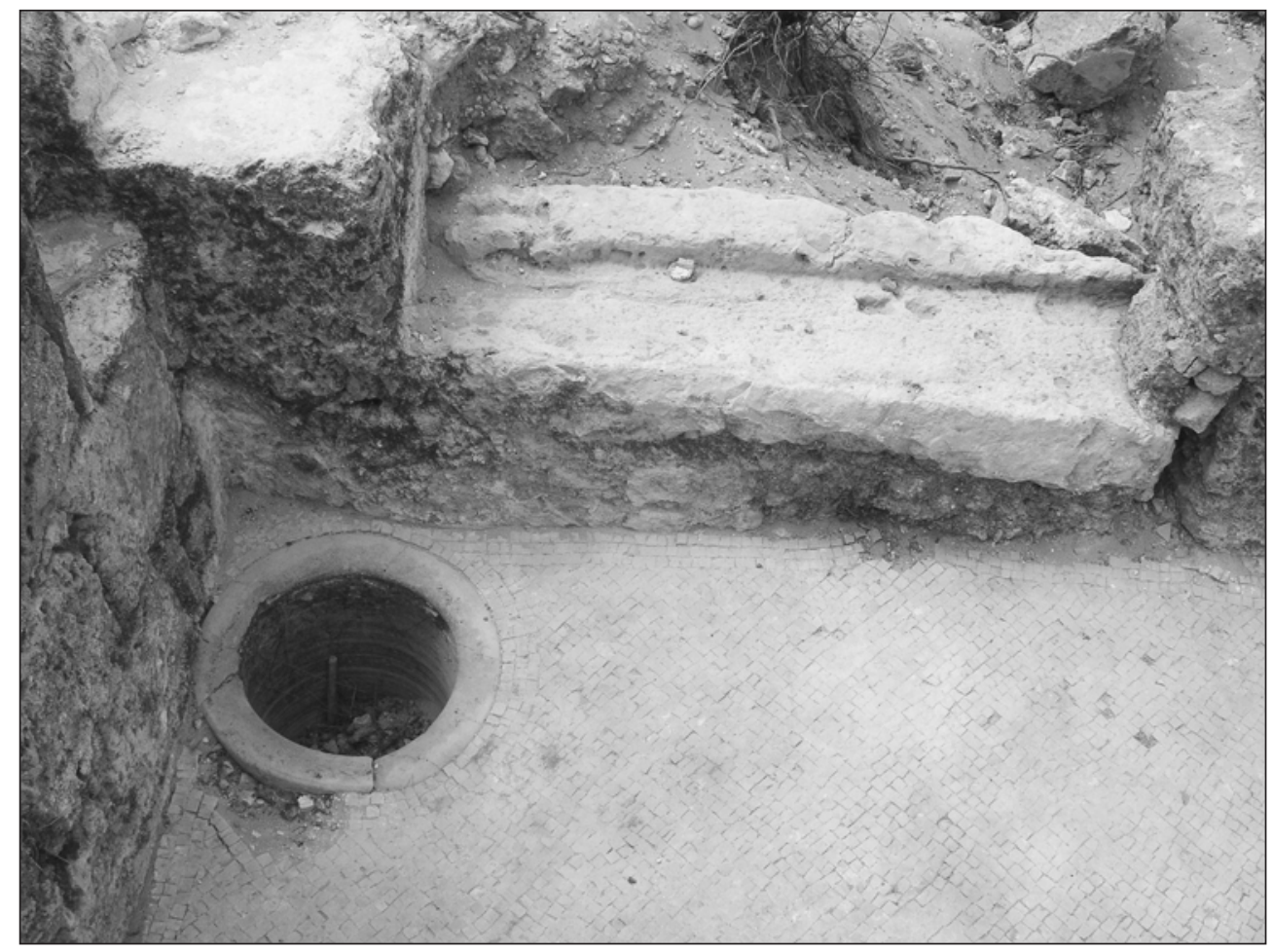

Fig. 14. Sunken vessel in room D47

(Photo T. Waliszewski) 


\section{APPENDIX 2 \\ PRELIMINARY REMARKS ON THRESHOLDS FROM PRIVATE HOUSES IN JIYEH (PORPHYREON)}

\section{Mariusz Gwiazda}

Antiquity of Southeastern Europe Research Centre, University of Warsaw, Institute of Archaeology, Cardinal Stefan Wyszyński University in Warsaw

In the course of explorations of the habitation district in Jiyeh (Porphyreon) 28 thresholds were documented in situ. All of them represent site occupation in the last, Romano-Byzantine phase. Most of the thresholds were made of single limestone or sandstone blocks. The top surface was carved on two levels: the narrower upper step and the wider but lower by a few centimeters lower step, which gives a lying L-shaped figure in cross-section. The dimensions are not standardized: the length ranges from $0.71 \mathrm{~m}$ to $1.63 \mathrm{~m}$ with a dominance of approximately $1.20 \mathrm{~m}$; the width is usually about $0.50 \mathrm{~m}(+/-0.10 \mathrm{~m})$, and the height from $0.20 \mathrm{~m}$ to $0.30 \mathrm{~m}$.

Five types of thresholds were distinguished in the presently documented set [Fig. 16] based on differences of shape and absence of openings on the steps. Type I [Fig. 17], has two rectangular openings at the ends of the higher step and no openings on the lower step for mounting the door pivots. The openings in the upper step are always long rectangles with the longer sides parallel to the long threshold axis. The exact localization varies in particular cases. Some openings adjoin the shorter edges of the threshold, while others are displaced a few centimeters toward the center of the threshold. A wooden embrasure cut appropriately to fit these openings was mounted in them and the door was hinged to this frame. One or more seldom two openings can be found approximately at one-third and two-thirds of the threshold length. The depth is from $2 \mathrm{~mm}$ to $4 \mathrm{~mm}$. Single openings are located usually on the right side of the threshold. These openings can be associated with a system of bolts serving to block the wings of the door.

Type II had openings for the door pivots on the lower step. These were always hidden behind the stone jambs, which rested partly on the upper step of the threshold. The number of openings in a threshold was not constant. In most cases there is one opening on each of the shorter

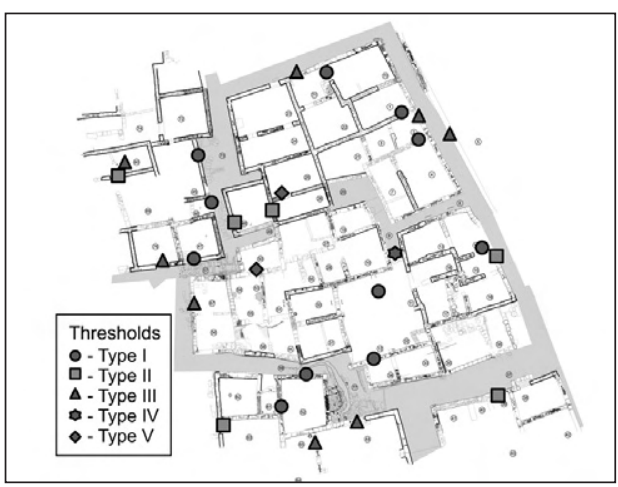

Fig. 15. Plan of the late Roman-Byzantine habitation district with localization of the different types of thresholds (Drawing K. Juchniewicz) 
edges. There are also examples of the pivot opening being located on just one side of the threshold, always to the right side when looking at the threshold from the side of the lower step. Similarly as in the first type, the bolt openings are on the lower step.
Type III had the pivot openings for the wings of the door on the lower step. The jambs that characterize type II are missing from this category. Instead of the jambs there was a wooden embrasure fitted into rectangular openings on the upper step.

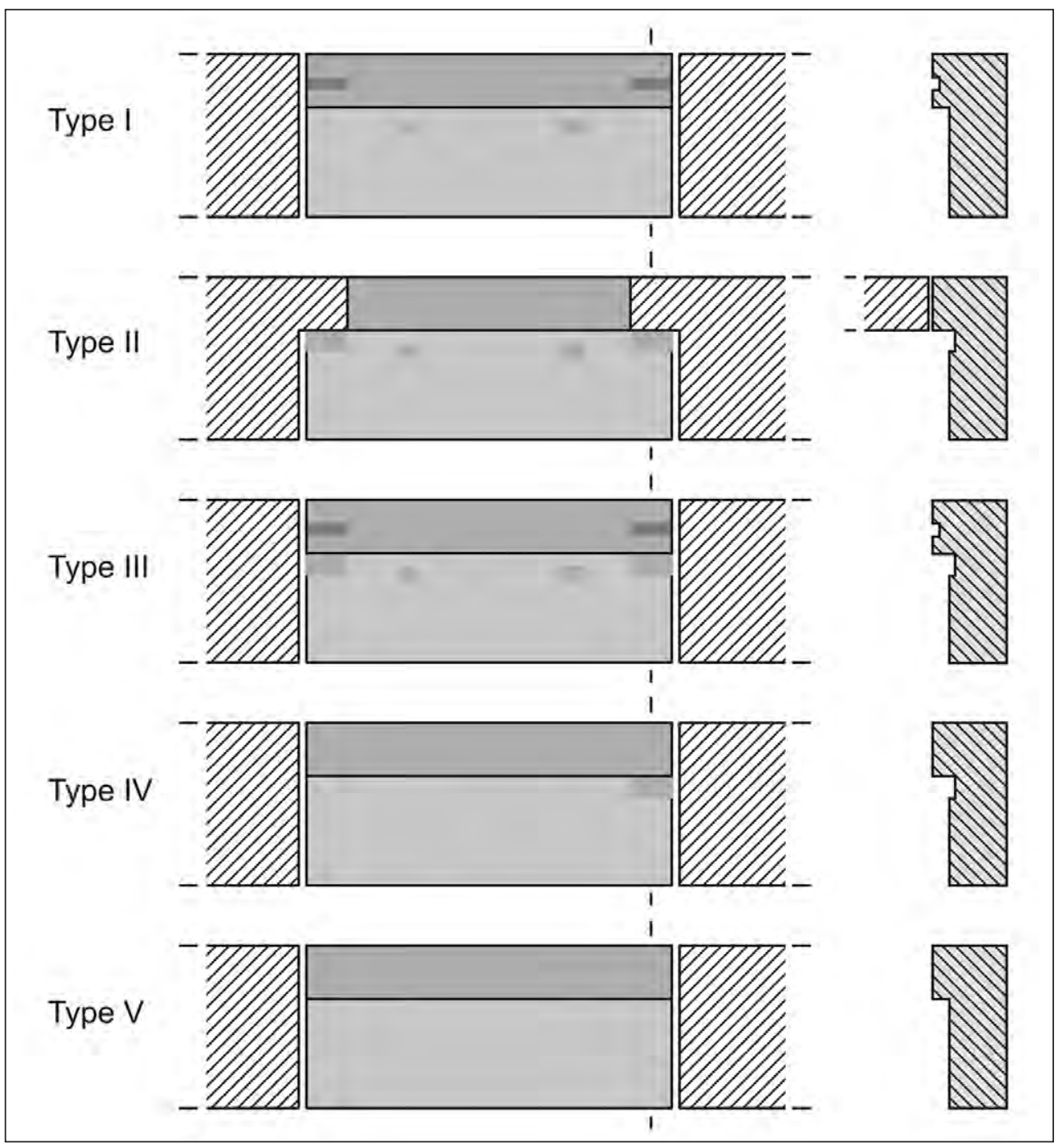

Fig. 16. Types of thresholds and sections

(Drawing M. Gwiazda) 
A wooden frame in this case ensured greater tightness of the door. Moreover, it was a relatively easy design to achieve requiring no special arrangement of dressing of stones for the jambs. Openings for bolting devices were observed on the lower step.

Type IV, similarly as types II and III, had openings for the door pivots but no jambs or fittings for a wooden embrasure.

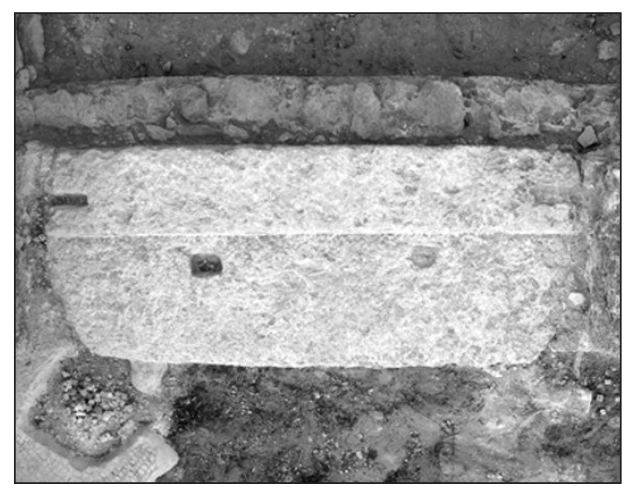

Fig. 17. Threshold of type I between room 45 and street 73 (Photo M. Gwiazda)
The last type $V$ had no openings at all. Its localization in the two known cases [Fig. 15], which placed them not siding the street, but inside complexes of rooms, suggests that there was no door in this passage.

The other threshold types occur by the street as well as inside complexes of rooms. In quantitative terms, types I and III were the most common, respectively eleven and eight examples. The other types were represented by six (type II), one (type IV) and two (type V) specimens. The number of openings for pivots and bolts on individual thresholds clearly points to a preference for double-wing doors. In all cases the doors opened to the inside. An analysis of the distribution of particular types of thresholds [see Fig. 15] demonstrates that two different kinds of thresholds could have been used in a single living complex, e.g., the complex of rooms 48-26-25 where types II and IV occurred.

Dr. Tomasz Waliszewski

Institute of Archaeology, University of Warsaw

00-927 Warsaw, Poland

ul. Krakowskie Przedmieście 26/28

twaliszewski@uw.edu.pl

Dr. Karol Juchniewicz

karol.juchniewicz@gmail.com

Mariusz Gwiazda

Antiquity of Southeastern Europe Research Centre, University of Warsaw

00-927 Warsaw, Poland

ul. Krakowskie Przedmieście 26/28

mariusz.gwiazda@gmail.com 


\section{REFERENCES}

Aliquot, J.

2004 Aegyptiaca et Isiaca de la Phénicie et du Liban aux époques hellénistique et romaine, Syria 81, 201-228

Bogacki, M.

2012 Ground and aerial photogrammetric documentation in Jiyeh (Porphyreon), PAM 21 (Research 2009), 454-458

Contenau, G.

1920 La mosaïque de Djiyé [in:] G. Contenau, Mission archéologique à Sidon (1914), Syria 1, 295-305

Domżalski, K., Wicenciak, U., El-Tayeb, M., Waliszewski, T.

2005 Late Hellenistic and Early Roman pottery production center at Jiyeh. Rescue excavations, 2004, PAM 16 (Reports 2004), 429-439

Edgar, C.C.

1906 Catalogue général des antiquités égyptiennes du Musée du Caire, nos 33301-33506. Sculptors'studies and unfinished works, Cairo: Institut français d'archéologie orientale

Elayi, J.

1996 Nouveaux éléments sur le mur à piliers phénicien, Transeuphratène 11, 77-94

Finkielsztejn, G.

2005 Les mosaïques de la komopolis de Porphyreon du sud (Kfar Samir; Haïfa, Israël): Un évêché (?) entre village et cité [in:] H. Morlier (ed.), La mosaïque gréco-romaine IX.1. Actes du IXe Colloque international pour l'étude de la mosaïque antique et médiévale, Rome, 5-10 novembre 2001 [=Collection de l'École française de Rome 352], Rome: École française de Rome, 435-452

Grimm, G.

1975 Kunst der Ptolemäer- und Römerzeit im Ägyptischen Museum Kairo, Mainz am Rhein: Philipp von Zabern

Henein, N.H., Wuttmann, M.

2000 Kellia II. L'ermitage copte QR 195, 1. Archéologie et architecture [=FIFAO 41], Cairo: Institut français d'archéologie orientale

Jounblat, F., Seeden, H., Atallah, M. (eds)

1989 Beiteddine. Past and Present, Beirut

Mundell Mango, $\mathrm{M}$.

1986 Silver from Early Byzantium. The Kaper Koraon and Related Treasures, Baltimore: The Walters Art Gallery

Renan, E.

1864 Mission de Phénicie, Paris: Imprimerie impériale

Saidah, R.

1975 Khan Khaldé, Dossiers de l'Archéologie 12, 50-59

1977 Porphyréon du Liban: une Pompéi byzantine enfouie sous le sable, Archéologia 104, 38-43 


\section{LEBANON}

Waliszewski, T.

2005 Jiyeh (Porphyreon). Explorations 2003-2004, PAM 16 (Reports 2004), 419-422

Waliszewski, T. et alii

2006 Jiyeh (Porphyreon). Hellenistic, Roman and Byzantine settlement on the southern coast of Lebanon. Preliminary report on 1997 and 2003-2005 seasons, BAAL 10, 5-80

Waliszewski, T., Wicenciak, U.

2007 (in collaboration with M. El-Tayeb, K. Juchniewicz) Jiyeh (Porphyreon). Explorations 2005, PAM 17 (Reports 2005), 421-429

Wicenciak, U.

2012 A local Hellenistic "Phoenician"type Amphora and other pottery vessels from excavations in Jiyeh (Porphyreon), (Seasons 2008-2009), PAM 21 (Research 2009), 446-453

Wicenciak, U., El-Tayeb, M., Domżalski, K., Waliszewski, T.

2003 Preliminary report on a salvage campaign at Jiyeh, 2004: The pottery production area, Swiatowit 46 A, 129-134 
POLISH CENTRE OF MEDITERRANEAN ARCHAEOLOGY UNIVERSITY OF WARSAW

\section{POLISH ARCHAEOLOGY IN THE MEDITERRANEAN}
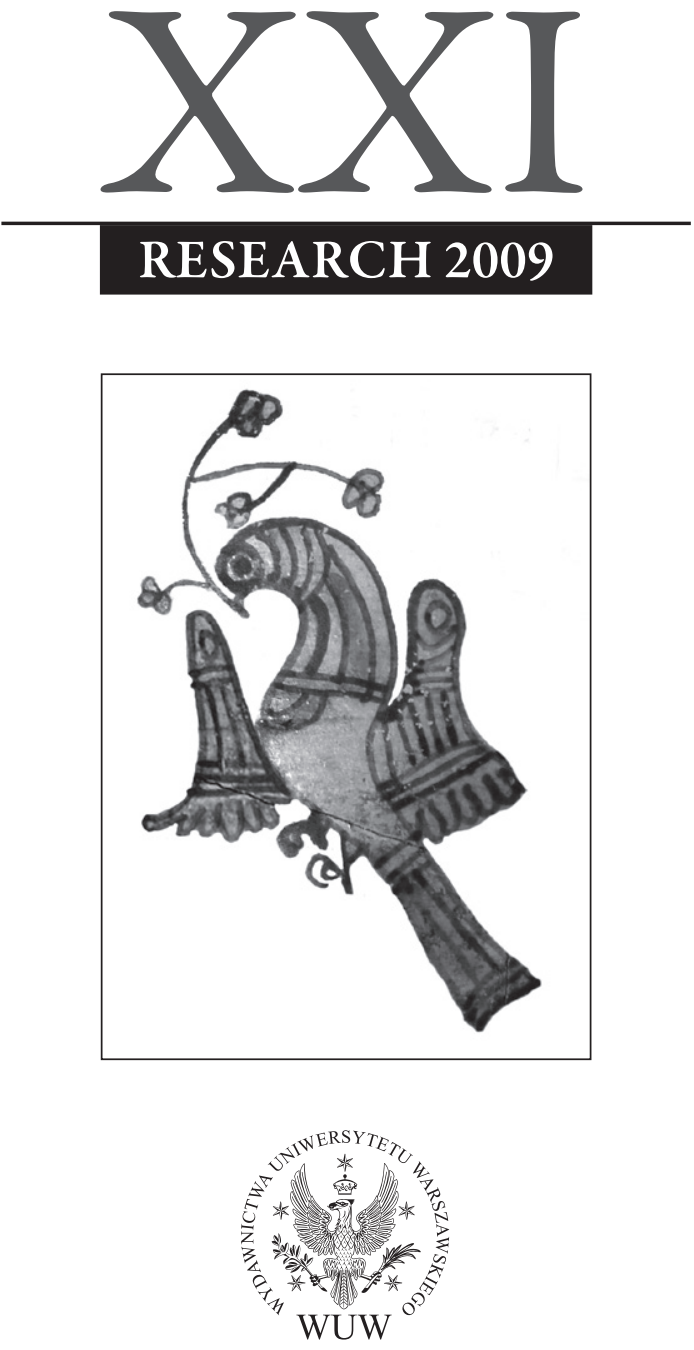


\section{CONTENTS}

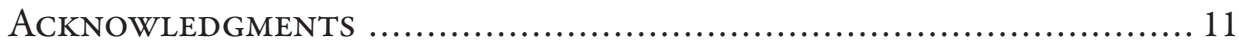

OBITUARIES

Aleksandra Krzyżanowska .............................................. 13

ABBREVIATIONS AND STANDARD REFERENCES …............................ 15

PAM REPORTS

PCMA FIELD MISSIONS AND PROJECTS IN 2009 (WITH MAP) 19

\section{EGYPT}

\section{ALEXANDRIA}

AlEXANDRIA KOM EL-DikKa: EXCAVATIONS AND PRESERVATION WORK.

PRELIMINARY REPORT 2008/2009

Grzegorz Majcherek

APPENDIX: AUdITORIUM E: EXPLORATION IN SEASON 2009

Karol Juchniewicz, Katarzyna Lach ..................................... 43

KoM EL-DikKa 2005-2009: SELECTED ANTHROPOLOGICAL RESEARCH

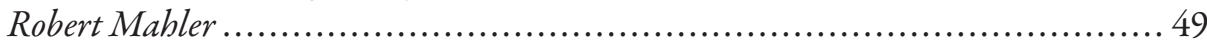

MAREA

MAREA. RePORT 2009

Hanna Szymanska, Krzysztof Babraj ................................................ 59

MAREA 2009: POTTERY FROM THE EXCAVATIONS

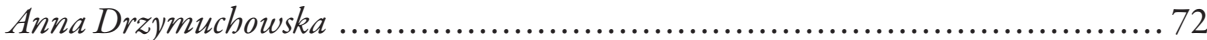

MARINA EL-ALAMEIN

Marina EL-Alamein. Conservation WORK IN THE 2009 SEASON

Stanistaw Medeksza, Rafat Czerner, Grażyna Bakowska with contributions by I. Fuks-

Rembisz, W. Grzegorek, G. Majcherek, M. Mrozek-Wysocka, P. Zambrzycki ...... 79 


\section{TELL EL-RETABA}

TELL EL-RETABA: SEASON 2009

Stawomir Rzepka, Jozef Hudec. 107 Appendix: Tell el-Retaba: Archaeobotanical Studies Claire Malleson

TELL EL-ReTABA 2009: THE POTTERY Anna Wodzińska....

TELL EL-FARKHA

Tell el-Farkha (Ghazala). Season 2009

Marek Chtodnicki, Krzysztof M. Ciatowicz

\section{SAQQARA}

SAQQARA 2008-2009

Karol Myśliwiec

APPENDIX: CONSERVATION WORK IN SAQQARA (2008-2009)

Zbigniew Godziejewski

SAQQARA 2008-2009: THE POTTERY

Teodozja I. Rzeuska

\section{NAQLUN}

NAQLUN (NeKLONI) EXCAVATIONS IN 2008-2009

Wtodzimierz Godlewski

APPENDIX: NAQLUN 2008: ARCHAEOBOTANICAL STUDIES

Jarostaw Zieliński

REFUSE DUMP IN SECTOR B IN NAQLUN: EXCAVATION REPORT 2008-2009

Tomasz Derda, Dorota Dzierzbicka

PotTERY FROM THE REFUSE DUMP UNDER UNIT B.26 IN NAQLUN

Katarzyna Danys-Lasek

TWO BURIALS FROM CEMETERY A IN NAQLUN: ARCHAEOLOGICAL

AND ANTHROPOLOGICAL REMARKS

Dorota Dzierzbicka, Marzena Ożarek

ON THE COLLECTION OF WOODEN FINDS FROM NAQLUN AGAIN

Jarostaw Zielinski, Iwona Zych

DEIR EL-BAHARI

Conservation work in the Hatshepsut Temple in Deir eL-BAhari (2009)

Rajmund Gazda

Sandstone sphinxes of Queen Hatshepsut from Deir el-Bahari: PRELIMINARY REMARKS Agata Smilgin 
Temple of Tuthmosis III In DeIR EL-BAHARI IN 2008 AND 2009: WORK IN THE STORES AND FIELD

Monika Dolinska

The Temple of Tuthmosis I Rediscovered

Jadwiga Iwaszczuk

\section{DAKHLEH OASIS}

Dakhleh OAsis Project. Petroglyph Unit: rock art Research, 2009

Ewa Kuciewicz, Michat Kobusiewicz

\section{SUDAN}

\section{OLD DONGOLA}

DoNGOLA 2008-2009

Wtodzimierz Godlewski

APPENDIX: CONSERVATION OF WALL PAINTINGS INSIDE THE FORMER THRONE

HALl of THE MAKURIAN KINGS IN DoNgOla (2009 SEASON)

Cristobal Calaforra-Rzepka

Dongola 2009: PotTery From BuILDING I (Kom A)

Katarzyna Danys-Lasek

WALL INSCRIPTIONS IN A BURIAL VAULT UNDER THE NORTHWEST ANNEX OF THE Monastery on Kom H (Dongola 2009)

Adam Eajtar, Jacques van der Vliet

Crypts 1 And 2 in the Northwest Annex of The Monastery on Kom H IN DONGOLA: REPORT ON THE EXPLORATION IN 2009

Wtodzimierz Godlewski, Robert Mabler, Barbara Czaja-Szewczak

EL-ZUMA

THE POTTERY FROM FOUR TUMULI GRAVES IN EL-ZUMA (2009)

Edyta Klimaszewska-Drabot, Ewa Czyżewska

FOURTH CATARACT

Research in the PCMA UW CONCESSION ON THE Fourth CataraCt

(HAMDAB DAM RESCUE PROJECT). INTERIM REPORT 2009

Marek Chtodnicki

Rock ART RESEARCH In THE Fourth CATARACT REgION, SEASON 2009

Ewa Kuciewicz, Andrzej Rozwadowski

EXCAVATIONS IN 2009 IN THE ENVIRONS OF EL-AR VILLAGE

(Fourth CATARACT REgion, SudAN)

Anna Longa

El-Ar 31: excavations of late/post-Meroitic tumuli. Preliminary Report Artur Buszek, Michat Kurzyk 


\section{CYPRUS}

\section{NEA PAPHOS}

Nea Paphos. Season 2009

Henryk Meyza in cooperation with Wiktor Andrzej Daszewski, Aleksandra Brzozowska, Joanna Michalska, Joanna K. Rądkowska, and Monika Więch. 407

\section{LEBANON}

\section{JIYEH}

PRELIMINARY REPORT ON THE 2008 AND 2009 EXCAVATION SEASONS AT JiYeH (PORPHYREON)

Tomasz Waliszewski, Karol Juchniewicz, Mariusz Gwiazda

APPENDIX 1. Sunken vessels in late Roman and ByZantine Houses

IN AREA D

Mariusz Gwiazda

APPENDIX 2. PRELIMINARY REMARKS ON THRESHOLDS FROM PRIVATE HOUSES IN JIYEH (PORPHYREON)

Mariusz Gwiazda

Local Hellenistic 'PHOENiCIAN'-TYPe AMPHORA AND OTHER POTTERY VESSELS FROM EXCAVATIONS IN JIYEH (PORPHYREON) (SEASONS 2008-2009)

Urszula Wicenciak 446

GROUND AND AERIAL PHOTOGRAMMETRIC DOCUMENTATION IN JIYEH (PORPHYREON)

Miron Bogacki

\section{SYRIA}

PALMYRA

Polish Archaeological Mission to Palmyra. Seasons 2008 and 2009

Grzegorz Majcherek

\section{HAWARTE}

EXCAVATIONS IN HaWARTE 2008-2009

Michat Gawlikowski

GLASS FINDS FROM THE MITHRAEUM IN HaWARTE

Krystyna Gawlikowska

TELL ARBID

TELl Arbid 2008-2009. Preliminary Report ON THE RESUlts OF THE THIRTEENTH AND FOURTEENTH SEASONS OF POLISH-SYRIAN EXCAVATIONS Piotr Bieliński 
Adam Mickiewicz University excavations in Sector P at Tell Arbid (SPRING2009)

Rafat Kolinski

TELL QARAMEL

Tell QARAmel: excavations 2009

Ryszard F. Mazurowski

\section{PAM STUDIES}

Adult burials of Ninevite 5 date on Tell Arbid (2007-2008)

Dariusz Szelag

Chariot terracotta models From Tell Arbid

Mattia Raccidi

New Protodynastic SEREKhS From the Nile Delta: THE CASE Of FindS FROM TELL EL-FARKHA

Mariusz A. Jucha

PITHOS-TYPE VESSELS FROM CHHÎM: PRELIMINARY ASSESSMENT OF FINDS FROM 1996-2009

Zofia Kowarska, Szymon Lenarczyk

Buildings on Site B at Naqlun (NeKloni)

Szymon Maślak

ZOOARCHAEOLOGICAL ANALYSIS OF MATERIAL FROM CISTERNS STR 1/96-97 AND HA/NEH 2.16.3 IN NeA PAPHOS

Ewelina Tepe

ANIMAL BONE REMAINS FROM SHEIKH ABD EL-GURNA:

ISSUES AND OPPORTUNITIES

Urszula Iwaszczuk

ANIMALS IN ROCK ART. RESULTS OF ARCHAEOZOOLOGICAL RESEARCH AT THe Site of El-Gamamiya 67 (Fourth Cataract, Sudan)

Marta Osypinska

INDEX OF SITES

GUIDELINES FOR AUTHORS 